\title{
Complete remission of disseminated Langerhans cell sarcoma after stem cell transplantation
}

\section{A case report}

\author{
Verena Schlintl · Konstantin Schlick · Gudrun Russ · Simon Peter Gampenrieder • Claudia Monzo Fuentes • \\ Tea Kos · Felix Renneberg • Lukas Rettenbacher · Johann Gradl · Karl Sotlar · Alexander Hoffmann · \\ Richard Greil (iD)
}

Received: 5 December 2019 / Accepted: 10 December 2019 / Published online: 15 January 2020

(c) The Author(s) 2020

\begin{abstract}
Summary With fewer than 100 cases described in the English literature so far, Langerhans cell sarcoma represents an orphan malignant disease deriving from histiocytic cells. Clinical course is extremely aggressive and associated with poor survival rates, especially in disseminated condition. Herein, we describe the case of a young patient with fulminant development of metastatic Langerhans cell sarcoma, who achieved persistent remission after polychemotherapy and subsequent high-dose chemotherapy with autologous stem cell transplantation.
\end{abstract}

Keywords Autologous stem cell transplantation . Chemotherapy

\section{Case report}

A 55-year-old woman first presented to a different department in August 2017 due to persistent cough with sputum, loss of weight and night sweat since one month. Medical history comprised bronchial asthma

\footnotetext{
V. Schlintl · K. Schlick · G. Russ · S. P. Gampenrieder • C. Monzo Fuentes · T. Kos · F. Renneberg ·

Univ. Prof. Dr. R. Greil ( $\square)$

Third Medical Department with Hematology, Medical Oncology, Hemostaseology, Rheumatology and Infectious Diseases, Oncologic Center, University Hospital Salzburg, Müllner Hauptstraße 48, 5020 Salzburg, Austria r.greil@salk.at

\section{Rettenbacher}

Department of Nuclear Medicine, University Hospital Salzburg, Müllner Hauptstraße 48, 5020 Salzburg, Austria

\section{J. Gradl}

Department of Radiology, University Hospital Salzburg, Müllner Hauptstraße 48, 5020 Salzburg, Austria

\section{K. Sotlar · A. Hoffmann}

Department of Pathology, University Hospital Salzburg, Müllner Hauptstraße 48, 5020 Salzburg, Austria
}

and positive smoking status with 15 pack-years. Arterial oxygen saturation was lowered and chest X-ray revealed micronodular pulmonary lesions atypical for an infection. In the computer tomography (CT) scan of thorax and abdomen multiple, partly confluating lesions in the lungs (Fig. 1a), liver and pancreas were detected, as well as suspicious peritoneal and osseous metastases.

In fluorodeoxyglucose positron emission tomography computed tomography (FDG PET CT) neoplastic retention was shown in countless, disseminated pulmonary, peritoneal, osseous and lymphatic lesions (Fig. 2a). Aspiration biopsy from the right lower lobe was conducted by means of bronchoscopy (Fig. 3a). However, cytology could not affirm malignant cells and testing for tumor markers was negative. Finally, a cervical lymph node was extirpated for further analysis. Immunohistochemistry revealed dense foci of CD68-positive histiocytic tumor cells and multinuclear giant cells of Langerhans type (Fig. 3b). Staining for TTF-1, p40, Melan-A, HMB45, CD20, CD3, CD21 and CD123 was negative; however S100 and CD1a were positive (Fig. 3c,d). Meeting the criteria of malignant cells, the scarce diagnosis of Langerhans cell sarcoma was made. FoundationOne ${ }^{\circledR}$ analysis revealed genomic alterations in MAP2K1 (MEK1), PTEN (loss), CXCR4, FAS (loss exons 2-9), SMARCA4, TNFRSF14 and TP53 without therapeutic implication. Tumor mutation burden (TMB) was low and BRAF was wildtype. Ki-67 accounted for $70 \%$ correlating with a rapid clinical course of disease. A transfer to our department took place after lymph node extirpation. From date of first presentation to introduction of therapy (lagtime 40 days), the patient developed an oxygen demand of six liters per minute.

Considering the young patient age, good pre-existing general condition and disseminated illness, we decided for subsequent polychemotherapy and stem cell 

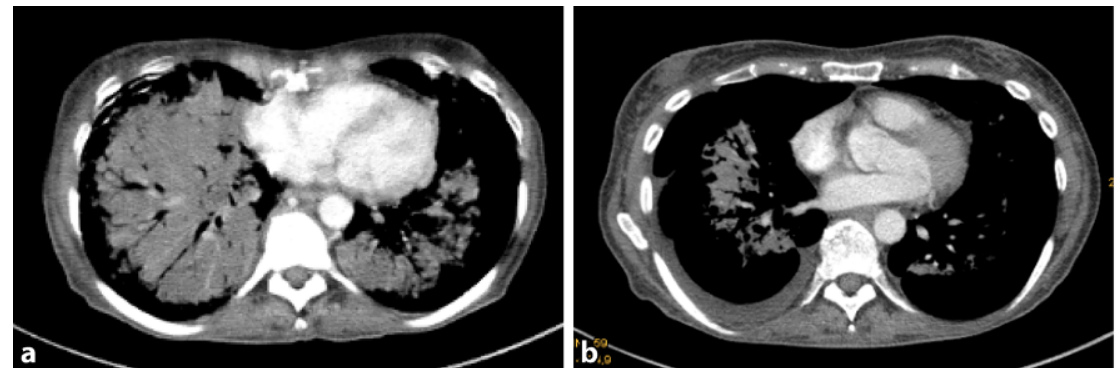

Fig. 1 Course of disease remission delineated by computed tomography of thorax: a at initial diagnosis, disseminated pulmonary metastases; $\boldsymbol{b}$ after one cycle of chemotherapy, partial remission; c one year after high-dose chemotherapy with autologous stem cell transplant, complete remission
Fig. 2 Course of disease remission delineated by whole body fluorodeoxyglucose positron emission tomography: a at initial diagnosis, disseminated pulmonary metastases; $\mathbf{b}$ after one cycle of chemotherapy, partial remission; c one year after high-dose chemotherapy with autologous stem cell transplant, complete remission
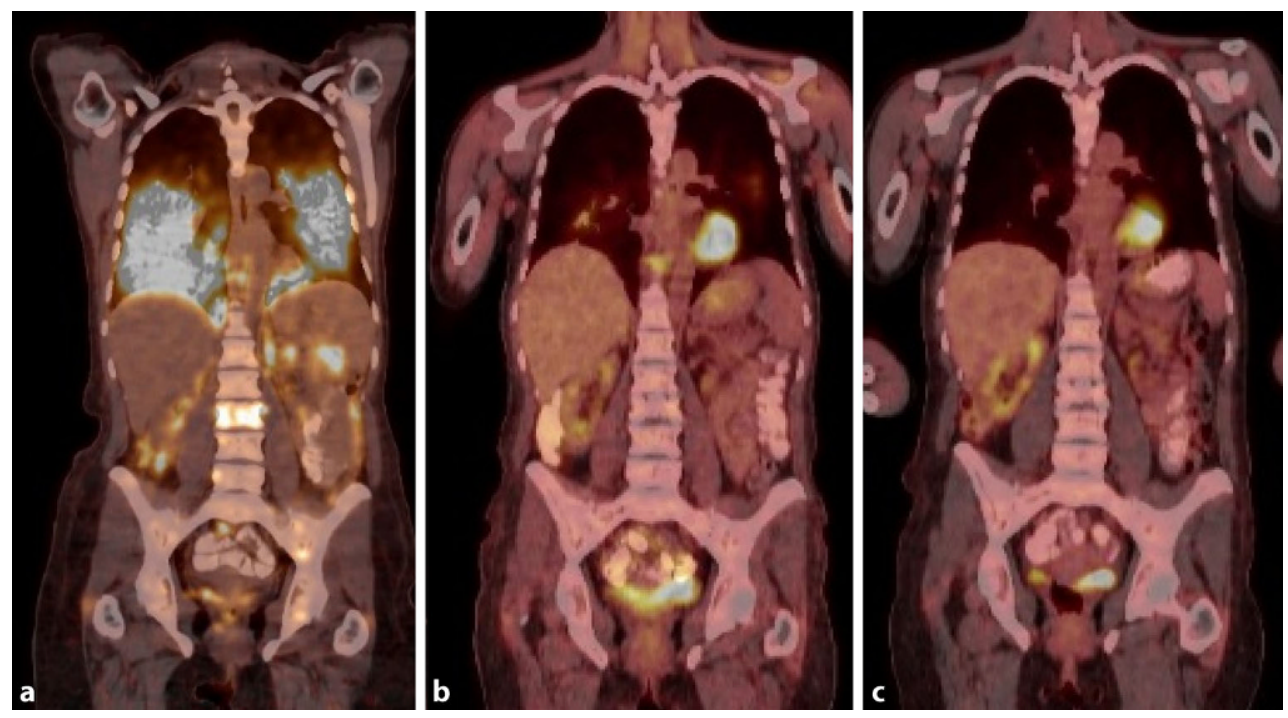

Fig. 3 Langerhans cell sarcoma: a hematoxylin and eosin stain; b lymph node infiltrate with Langerhans cells; c expression of $\mathrm{CD} 1 \mathrm{a} ; \mathbf{d}$ expression of $\mathrm{S} 100$
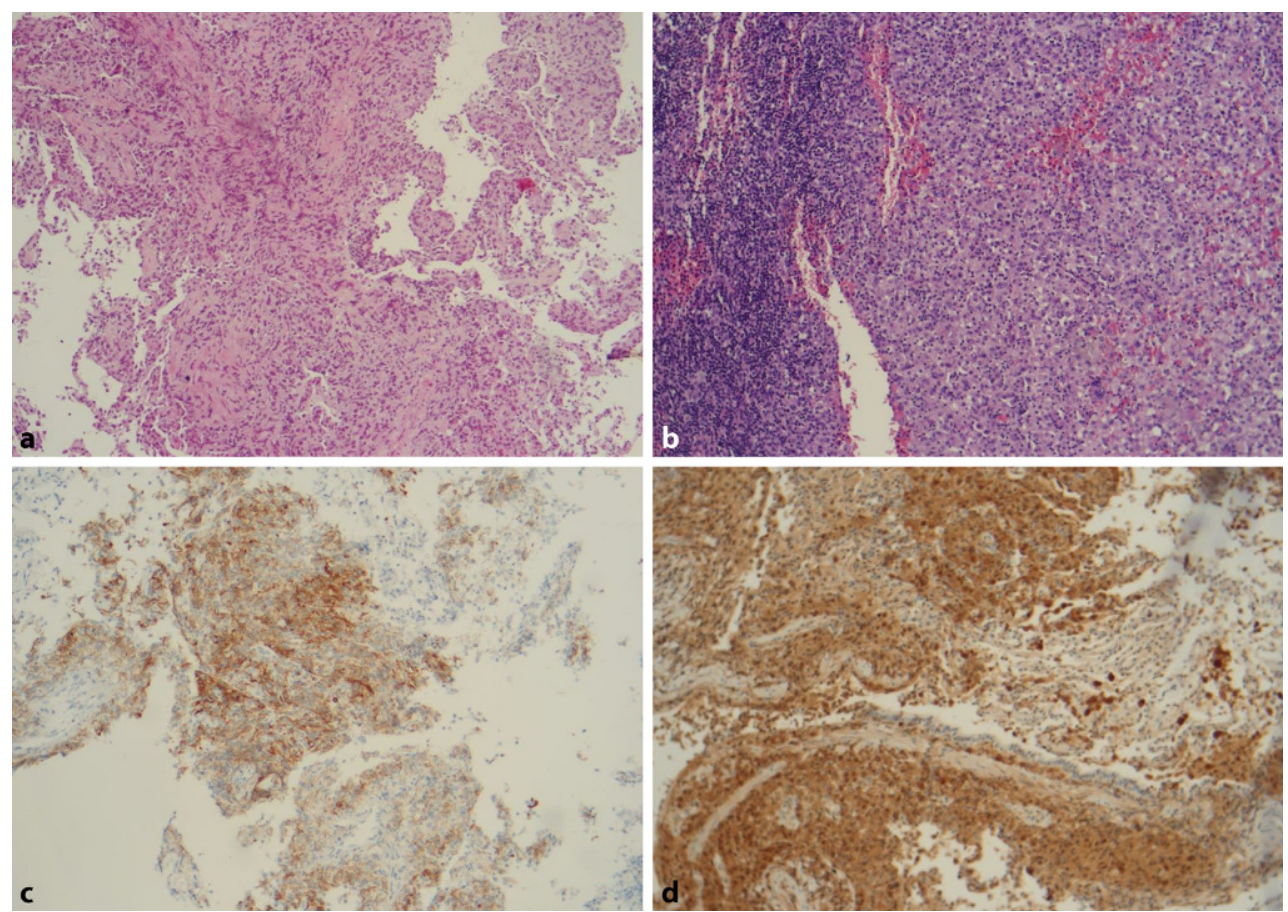
Table 1 Treatment options. Data adopted from [2]

\begin{tabular}{|l|l|}
\hline Treatment modality & $\begin{array}{l}\text { Proportion of treated } \\
\text { patients (\%) }\end{array}$ \\
\hline Chemotherapy & 71 \\
\hline Surgery & 47 \\
\hline Radiotherapy & 15 \\
\hline Stem cell transplantation & 6 \\
\hline No therapy & 6 \\
\hline aAlone or in combination & \\
\hline
\end{tabular}

transplantation. In September 2017, the patient received a preliminary phase with vinblastine $\left(3 \mathrm{mg} / \mathrm{m}^{2}\right.$ on day 1) and dexamethasone (40 mg on days 1-3), followed by primary chemotherapy with six cycles of cyclophosphamide $\left(750 \mathrm{mg} / \mathrm{m}^{2}\right.$ on day 1$)$, doxorubicin (50 $\mathrm{mg} / \mathrm{m}^{2}$ on day 1$)$, vincristine $\left(1.4 \mathrm{mg} / \mathrm{m}^{2}\right.$ on day 1$)$, and prednisolone $\left(40 \mathrm{mg} / \mathrm{m}^{2}\right.$ on days $\left.1-5\right)$ (CHOP). The first cycle already led to a good partial remission (Fig. $1 \mathrm{~b}$ and $2 \mathrm{~b}$ ); oxygen demand was reduced to two liters per minute. After reaching complete remission and successful stem cell apheresis, high-dosage therapy with carmustine $\left(300 \mathrm{mg} / \mathrm{m}^{2}\right.$ on day 1$)$, cytarabine ( $400 \mathrm{mg} / \mathrm{m}^{2}$ on days $\left.2-5\right)$, etoposide $\left(200 \mathrm{mg} / \mathrm{m}^{2}\right.$ on days $1-5)$, and melphalane $\left(120 \mathrm{mg} / \mathrm{m}^{2}\right.$ on day 6$)$ with subsequent autologous stem cell transplantation was administered in May 2018. At the present time, one year later, the patient is in excellent general condition without oxygen demand and complete remission is still persisting (Fig. 1c and 2c).

\section{Critical discussion and review of the literature}

Langerhans cell sarcoma (LCS) is a rare malignant disease deriving from antigen-presenting cells within the histiocytic system [1]. Given its extreme scarcity with less than 100 cases reported in the English literature so far, there is a lack of evidence regarding the most appropriate treatment regimen [2].

In contrast to Langerhans cell histiocytosis ( $\mathrm{LCH})$, LCS is characterized by an aggressive clinical course and overtly malignant cytologic features [3]. The most frequent sites of presentation are lymph nodes (75\%), followed by the skin $(50 \%)$, lung, liver, and spleen [2]. Langerhans cells typically show longitudinally grooved nuclei and Birbeck granules and are confirmed by positive immunohistochemical staining for CD1a, CD207 (Langerin) and S-100 protein [4]. Overall survival in patients with LCS is reported for $58 \%$ at 1 year and $28 \%$ at 5 years. With increase of tumor burden survival rates even deteriorate significantly. Until now, no case achieving 5-year survival in disseminated disease has been described [2].

As it comes to treatment options (Table 1), multimodality therapy seems to be beneficial. In patients with single-site involvement $(33 \%)$ or locoregional disease $(26 \%)$ complete surgical excision is recommended. In case of positive resection margins, immunosuppression, or simultaneous hematolog- ical disease, adjuvant chemotherapy or combined chemoradiotherapy seems to be effective. For patients with disseminated disease (41\%) high-dose chemotherapy and autologous stem cell transplantation appears to be a reasonable and potentially curative treatment option. However, so far only a few cases of stem cell transplantation in LCS have been reported, three of which achieved complete remission [5-7].

\section{Conclusion}

Langerhans cell sarcoma is an extremely rare disease associated with poor clinical outcome. Due to a lack of data, standard treatment regimens have not been established yet. With this case report, we want to emphasize the role of high-dose chemotherapy and autologous stem cell transplantation as a curative treatment option for patients with disseminated disease. In addition, the case supports the necessity for a rapid clarification of diagnosis in such situations.

Funding Open access funding provided by Paracelsus Medical University.

Conflict of interest V. Schlintl, K. Schlick, G. Russ, S. Gampenrieder, C. Monzo Fuentes, T. Kos, F. Renneberg, L. Rettenbacher, J. Gradl, K. Sotlar, A. Hoffmann and R. Greil declare that they have no competing interests.

Open Access This article is licensed under a Creative Commons Attribution 4.0 International License, which permits use, sharing, adaptation, distribution and reproduction in any medium or format, as long as you give appropriate credit to the original author(s) and the source, provide a link to the Creative Commons licence, and indicate if changes were made. The images or other third party material in this article are included in the article's Creative Commons licence, unless indicated otherwise in a credit line to the material. If material is not included in the article's Creative Commons licence and your intended use is not permitted by statutory regulation or exceeds the permitted use, you will need to obtain permission directly from the copyright holder. To view a copy of this licence, visit http://creativecommons.org/licenses/by/4.0/.

\section{References}

1. Male D, Brostoff J, Roth DB, Roitt IM. Lymphoid organs immunology. Amsterdam: Elsevier; 2013.

2. Howard JE. Langerhans cell sarcoma: a systematic review. Cancer Treat Rev. 2015;41(4):320-31. https://doi.org/10. 1016/j.ctrv.2015.02.011.

3. Pileri SA, Grogan TM, Harris NL, et al. Tumours of histiocytes and accessory dendritic cells: an immunohistochemical approach to classification from the international lymphoma study group based on 61 cases. Histopathology. 2002;41:1-29.

4. Jaffe ES, Harris NL, Stein H, Vardiman JW. Pathology and genetics of tumours of haematopoietic and lymphoid tissues. WHO classification of tumours. Lyon: IARC Press; 2001. p. 283.

5. Sagransky MJ, Deng AC, Magro CM. Primary cutaneous langerhans cell sarcoma: a report of four cases and review of the literature. Am J Dermatopathol. 2013;35:196-204. 
6. Ratei R, Hummel M, Anagnostopoulos I, et al. Common clonal origin of an acute B-lymphoblastic leukaemia and a langerhans cell sarcoma: evidence for hematopoietic plasticity. Haematologica. 2010;95:1461-6.

7. Chung WD, Im SA, Chung NG, Park GS. Langerhans cell sarcomain two young children: imaging findings on initial presentation and recurrence. Korean J Radiol. 2013;14:520-4.

- For latest news from international oncology congresses see: http://www.springermedizin.at/ memo-inoncology

Publisher's Note Springer Nature remains neutral with regard to jurisdictional claims in published maps and institutional affiliations. 